\title{
Field methods for the study of ants in sugarcane plantations in Southeastern Brazil
}

\author{
Débora Rodrigues de Souza ${ }^{1}$; Erich Stingel²; Luiz Carlos de Almeida²; Marco Antônio \\ Lazarini ${ }^{2}$; Catarina de Bortoli Munhae ${ }^{3}$; Odair Correa Bueno ${ }^{3}$; Claudinei Rogério \\ Archangelo ${ }^{4}$ : Maria Santina de C. Morini ${ }^{1 *}$ \\ ${ }^{1}$ UMC/NCA - Lab. de Mirmecologia, Av. Dr. Cândido Xavier de Almeida e Souza, 200 - 08701-970 - Mogi das \\ Cruzes, SP - Brasil. \\ ${ }^{2}$ CTC, Fazenda Santo Antônio, s/n, C.P. 162 - 13400-970 - Piracicaba, SP - Brasil. \\ ${ }^{3}$ UNESP/Centro de Estudos de Insetos Sociais, Av. 24, 1515 - 13506-725 - Rio Claro, SP - Brasil. \\ ${ }^{4}$ Usina Nova América S/A Agrícola - R. 11 de junho, 246 - 19800-020 - Assis, SP - Brasil. \\ *Corresponding author<morini@umc.br>
}

\begin{abstract}
The harvest of sugarcane is still traditionally done manually with the burning of straw in most cultivated areas in Brazil. However, burning has been gradually eliminated with the relatively recent use of mechanical harvesting. This will result in significant changes in the agroecosystem, as the straw will remain in the field. No investigation on Formicidae found in sugarcane plantations in Southeastern Brazil harvested by this new system has been done yet. Because of their feeding habits, many species of this family may act as predators of several sugarcane pests. In this study, the sampling efficacy of pitfall traps, baits, and underground traps with two types of attractants were evaluated. Pitfall traps gave the largest richness, while abundance was the highest from baiting. Community composition and structure differed in relation to the sampling methods used. The myrmecofauna collected with the same method with different baits was similar. Pitfall trapping was the most efficient method in this type of ecosystem; and sardine, the best attractant, due to its easy handing in the field.
\end{abstract}

Key words: pitfall, underground traps, baits, predatory ants, sampling methods

\section{Métodos de campo para o estudo de formigas em cultivo de cana-de-açúcar na região sudeste do Brasil}

\begin{abstract}
RESUMO: A colheita de cana-de-açúcar é efetuada manualmente e com a queima da palha em grande parte da área de cultivo. Porém, esse manejo deverá ser completamente substituído pela mecanizado. O emprego desse sistema de colheita é relativamente recente e pode resultar em alterações significativas no agroecossistema, em função da manutenção da palha no ambiente. Descrições sobre métodos de coleta de Formicidae, cujas espécies podem ser predadoras de diversas pragas da cultura, ainda são inexistentes em agroecossistemas que usam esse novo tipo de manejo. Assim, o objetivo do trabalho foi avaliar o uso de diferentes métodos de coleta: pitfall, isca e armadilhas subterrâneas; sendo os dois últimos com dois tipos de atrativos. A maior riqueza foi obtida com pitfall e a maior abundância com isca; a composição e a estrutura das comunidades diferem em relação ao método usado. A fauna coletada com um mesmo método, porém com atrativos diferentes, é similar. O uso de pitfall proporciona a amostragem da fauna predadora do cultivo, o que é importante para os programas de controle natural de pragas; e para quantificar a abundância da maior parte dessa fauna, a sardinha é o melhor material atrativo, devido à facilidade de manipulação no campo.

Palavras-chave: pitfall, armadilha subterrânea, iscas, formigas predadoras, métodos de coleta
\end{abstract}

\section{Introduction}

Sugarcane (Saccharum officinarum L.) fields cover nearly $7.10^{6}$ ha in Brazil, being second only to soybean and corn. As an important socioeconomic crop, it provides raw material for three agro-industries: sugar, spirits, and ethanol (CONAB, 2009; UNICA, 2009). The 2008/2009 crop estimates are 571 million tons of sugarcane, 26.6 billion liters of ethanol, and 32.1 million tons of sugar. São Paulo state is the main producer of sugarcane and its by-products in Brazil, accounting for more than $60 \%$ of all the sugar and alcohol production and $70 \%$ of the Brazilian exports of these products (Florentino et al., 2008; FNP, 2008; CONAB, 2009).

Despite authors demonstrate the role of ants in agroecosystems as pest control agents (Negm and Hensley, 1969; Rossi and Fowler, 2004; Peng and Christian, 2005), few studies have been made on Formicidae in sugarcane plantations. In general, ants are very diverse and abundant and are considered the most common generalist predators in tropical forests (Rossi and Fowler, 2004). In cultivated areas, ant species richness is low (Adams et al., 1981; Risch and Carrol, 1982; Botelho et al., 1986), but the remaining species may act as pest control agents (Fernandes et al., 1994).

Sci. Agric. (Piracicaba, Braz.), v.67, n.6, p.651-657, November/December 2010 
Currently, manual surgarcane harvesting with leaf burning is being gradually replaced with mechanical harvesting, which does not require burning. This study evaluated three ant sampling methods, pitfall trapping, baiting, and underground trapping applied to the study of ant communities in areas where this new mechanical harvest technique has been implemented. More specifically, richness and abundance were determined, and the composition and community structure were analyzed according to each technique.

\section{Material and Methods}

The study site is located in Paraguaçu Paulista $\left(22^{\circ} 24^{\prime} 46^{\prime \prime}\right.$ S, $50^{\circ} 34^{\prime} 33^{\prime \prime}$ W) state of São Paulo, Brazil, and is comprised of six stands of sugarcane variety SP81-3250. The culture routine was not disrupted by this study. The soil was prepared by conventional tilling and fertilization techniques at the time of planting before the establishment of the plantation. During the experimental phase, mechanical harvesting was carried out straw burning, which remained in the field during ant sampling.

Ants were collected from May 2006 to August 2008, a period that corresponded to three sugarcane plantation-harvest cycles. In the first cycle, the soil surface is characterized by the absence of straw burning. In the second cycle, straw of two harvests overlapped, the plant material remaining from the first harvest and from the last cycle. The stands of each experimental plot consisted of 60 120-m long lines randomly chosen, corresponding to an area of approximately 1 ha. In the beginning of each cycle, six sampling points were defined in two sugarcane rows in the center of experimental plots for each technique, in such a way that they were $30 \mathrm{~m}$ apart, as proposed by Sarmiento-M (2003). The same sampling points were used during the entire experimental period. The sampling methods used were: (i) pitfall trapping with traps made of 2-L PET bottles $8 \mathrm{~cm}$ tall and $9 \mathrm{~cm}$ in diameter attached with a 16-cm-diameter plastic funnel; the bottle was buried on the ground with the funnel rim level with the ground surface. The bottles were filled with $500 \mathrm{~mL}$ of water with $25 \mathrm{~g}$ of salt added with two drops of neutral detergent. Six traps were set per experimental plot, as proposed by Bestelmeyer et al. (2000) and left in the field for seven days; (ii) baits using water-diluted honey $(1: 1)$ and sardines in edible vegetable oil as attractant were placed in different Falcon tubes. Six tubes with one bait type each were placed and left on the soil surface for $1 \mathrm{~h}$; and (iii) underground traps were made with photographic film canisters with 3-mm holes, as proposed by Morini et al. (2004). Each trap consisted of two canisters, in which was placed one type of bait, either water-diluted honey (1:1) or sardine preserved in edible vegetable oil. Six traps were buried at a depth of $10 \mathrm{~cm}$ from the ground surface for seven days. After sampling, the collected ants were transferred to containers filled with $70 \%$ ethanol.

The material was initially identified by genera (Bolton, 1994) and then by morphospecies. Species iden- tification was carried out by comparison with the Formicidae collection of the Museum of Zoology of the University of São Paulo, Brazil (MZUSP), and the pertinent literature. Classification followed Bolton et al. (2006).

Total richness was defined as the number of species sampled with each of the techniques that were used. The relative frequency of occurrence was calculated as the total number of records of each species for each technique using presence and absence records. Abundance was calculated as the number of total individuals of each species. The accumulation and richness estimation curves were obtained using the software EstimateS 8.0 (Colwell, 2007); all calculations were randomized 100 times. The richness and abundance data obtained by each method were compared using the Kruskal-Wallis and Dunn tests with software Bioestat (Ayres et al., 2007).

To compare the communities obtained with the investigated sampling methods, the matrix of the sum of species records obtained with each technique was analyzed the with Bray-Curtis dissimilarity index (Legendre and Legendre, 1998) using the software R.

\section{Results and Discussion}

The total of 43,282 collected ants was assigned to five subfamilies, 19 genera, and 45 species (Table 1). Myrmicinae, Formicinae, Dolichoderinae, Ectatomminae, and Ponerinae, which represented 36\% of the subfamilies found in the neotropics, were collected using all sampling methods. Regardless of the used methods, Myrmicinae was the richest and most abundant subfamily (Figure 1). The diverse feeding and nesting habits of its species (Fowler et al., 1991) may be the reason why it is the most widely distributed taxon in the neotropics (Ward, 2000; Fernández, 2003). In general, the richest and most abundant subfamily results in the sugarcane agroecosystem are quite similar to those obtained by Mentone et al. (2009), who analyzed ant communities in an agroecosystem using direct seeding in corn, sorghum, and bean crops, in Southeastern São Paulo State, but used Moericke traps as a sampling method.

Species richness $(87 \%)$ was higher using pitfall traps. This may have been due to the time of permanence of the trap in the field and the water in the traps, which is an attractant (Luff, 1975; Delsinne et al., 2008) and may also have prevented the ants from escaping. This method is often used to estimate the abundance and species composition of ground surface-active ants (Bestelmeyer et al., 2000) and is included in the ALL biodiversity study protocol (Alonso and Agosti, 2000). However, when choosing this method, the diameter and depth of the trap must be taken into account (Pendola and New, 2007; Santos et al., 2007), as well as the goal of the study and the taxonomic group, so that the population is not misestimated (Morris et al., 1999). Regarding abundance, baiting was the most effective method, sampling mainly Pheidole sp. 35 and Dorymyrmex brunneus (Forel, 1908), regardless of the attractant that was used. These genera are consid- 
Table 1 - Relative occurrence and abundance frequency of taxa as a function of sampling method in a sugarcane plantation.

\begin{tabular}{|c|c|c|c|c|c|}
\hline \multirow{2}{*}{ Taxa } & \multicolumn{2}{|c|}{ Bait } & \multicolumn{2}{|c|}{ Underground trap } & \multirow{2}{*}{ Pitfall } \\
\hline & Sardine & Honey & Sardine & Honey & \\
\hline & 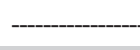 & 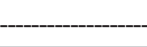 & \% & 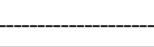 & (1) \\
\hline \multicolumn{6}{|l|}{ DOLICHODERINAE } \\
\hline Dorymyrmex brunneus (Forel, 1908) & $29(34.99)$ & $27(47.39)$ & $14.44(3.66)$ & $12.05(4.61)$ & $15(41.84)$ \\
\hline Linepithema iniquum (Mayr) & $1.7(0.02)$ & & & & \\
\hline
\end{tabular}

\section{ECTATOMMINAE}

Ectatomma tuberculatum (Olivier, 1791)

Gnamptogenys striatula Mayr, 1884

\section{FORMICINAE}

Brachymyrmex heeri Forel, 1874

Brachymyrmex incisus Forel, 1912

$6.6(2.01) \quad 14(2.90)$

$1.11(0.40)$

$1.20(0.21)$

Camponotus rufipes (Fabricius, 1775)

$40(80.96)$

$43.37(79.3) \quad 13(4.71)$

Camponotus sp.4

$1.3(0.04)$

Camponotus sp. 8

$1.3(0.04)$

Camponotus sp. 11

$0.4(0.01)$

\section{MYRMICINAE}

$1.7(0.48)$

Acromyrmex niger (Smith, F., 1858)

$1.7(0.20)$

Apterostigma sp.2

$3.4(0.38)$

Atta sexdens (Linnaeus, 1758)

$1.3(0.61)$

Mycocepurus sp.1

$0.4(0.02)$

Trachymyrmex urichi (Forel, 1893)

$0.8(0.15)$

Crematogaster (Gr. Orthocrema)

$0.4(0.01)$

Crematogaster sp. 5

$1.11(0.02)$

$0.4(0.05)$

Crematogaster sp.7

$0.8(0.02)$

$3.0(0.33)$

Strumigenys elongata Roger, 1863

Pheidole sp.2

Pheidole sp.4

$0.8(0.01)$

Pheidole sp.5

$15(2.46)$

$6.3(3.86)$

$0.8(0.22) \quad 0.8(0.01)$

Pheidole sp.6

$0.8(0.21) \quad 0.8(0.86)$

$0.4(0.01)$

Pheidole sp.20

Pheidole sp.21

Pheidole sp.22

Pheidole sp.24

$0.8(0.60)$

$0.8(0.02)$

Pheidole sp.27

$2.5(1.18) \quad 0.8(0.11)$

$0.8(2.64) \quad 1.6(0.15)$

$1.7(0.64) \quad 2.4(0.31)$

$4.44(5.40)$

$8.43(1.03)$

$10(2.560)$

Pheidole sp. 28

Pheidole sp.34

Pheidole sp.35

Pheidole sp. 38

Pheidole sp.42

$1.7(0.45) \quad 24(0.58)$

$1.11(2.81)$

$2.1(0.77)$

$0.8(0.23)$

$0.8(0.01)$

$2.5(1.24)$

Pheidole sp.45

$30(54.07) 29(43.36)$

$7.1(0.21)$

Solenopsis saevissima (Smith, 1855)

$8.3(0.50) \quad 7.1(0.25) \quad 3.33(0.11)$

$2.22(0.03)$

$1.20(0.28) \quad 0.8(0.04)$

Solenopsis (Diplorhoptrum)

$\begin{array}{lll}1.11(0.06) \quad 2.41(0.76) & 0.4(0.31) \\ & & 0.4(0.01)\end{array}$

$1.11(4.54)$

$2.5(0.54)$

$25.56(1.93)$

$24.10(12) \quad 15(43.80)$

\begin{tabular}{|c|c|c|c|c|}
\hline & & $1.1(0.02)$ & $1.20(0.83)$ & \\
\hline \multirow[t]{3}{*}{$8.3(0.50)$} & $7.1(0.25)$ & $3.33(0.11)$ & $4.82(0.89)$ & $2.1(0.31)$ \\
\hline & & & $1.19(0.14)$ & $1.3(0.04)$ \\
\hline & & & & $0.4(0.72)$ \\
\hline
\end{tabular}

Sci. Agric. (Piracicaba, Braz.), v.67, n.6, p.651-657, November/December 2010 
Table 1 - Continuation.

\section{PONERINAE}

Anochetus sp.2

$4.7(0.18)$

Hypoponera sp.1

$1.11(0.05)$

Hypoponera sp.2

Hypoponera sp.4

$2.22(0.05)$

$0.4(0.01)$

Odontomachus affinis Guérin-Méneville, 1844

$0.4(0.01)$

Odontomachus meinerti Forel, 1905

$1.7(0.05)$

Odontomachus chelifer (Latreille,1802)

$0.4(0.05)$

Pacbycondyla striata Fr. Smith, 1858

$1.3(0.06)$

Pacbycondyla sp.6

$2.5(0.10)$

Partial richness

Partial abundance

Total richness

Total abundance

$0.4(0.01)$

\begin{tabular}{rrrrr}
14 & 13 & 14 & 10 & 39 \\
\hline 8,051 & 9,384 & 6,254 & 1,454 & 8,139
\end{tabular}

Table 2 - Results of the Dunn test for richness and (abundance) per sampling method used in a sugarcane plantation.

\begin{tabular}{lcccc}
\hline & Baiting-sardine & Baiting-honey & Underground traps-sardine & Underground traps-honey \\
\hline \multirow{2}{*}{ Baiting-honey } & $0.0068 \mathrm{~ns}$ & & \\
& $(0.6137 \mathrm{~ns})$ & & \\
\hline \multirow{2}{*}{ Underground traps-sardine } & $0.4049 \mathrm{~ns}$ & & \\
& $(0.4858 \mathrm{~ns})$ & & $3.0376 *$ \\
\hline \multirow{2}{*}{ Underground traps-honey } & $3.4424 *$ & $3.4356 *$ & $(0.3651 \mathrm{~ns})$ & $9.2133 *$ \\
\hline \multirow{2}{*}{ Pitfall trapping } & $(0.1206 \mathrm{~ns})$ & $(0.7343 \mathrm{~ns})$ & $(3.4969 *)$ & $(3.8620 *)$ \\
\hline
\end{tabular}

$* p \leq 0.05 ;$ ns $=$ non significant.
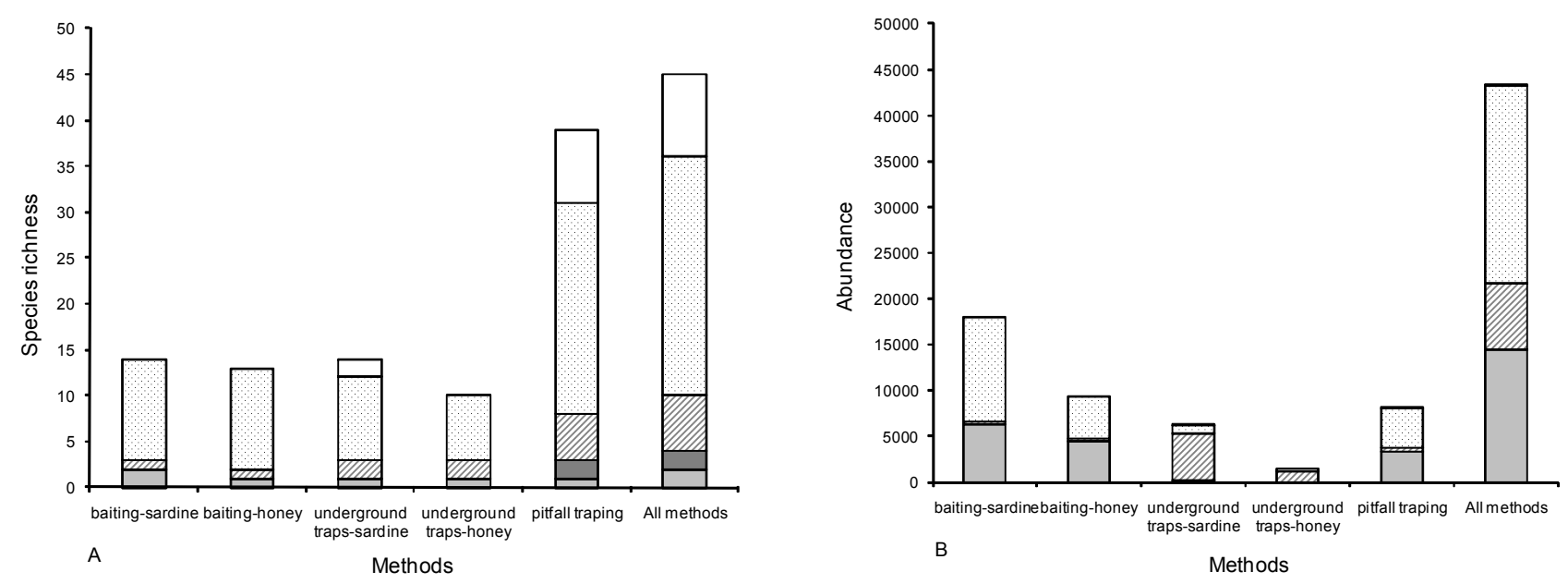

Figure 1 - Richness (A) and abundance (B) of subfamilies, based on the sampling methods ( $\square$ Ponerinae, $\square$ Mymicinae, $\square$ Formicinae, $\square$ Ectatomminae and $\square$ Dolichoderinae)

ered major predators of D. saccharalis (Fabr.) (Rossi and Fowler, 2004), one of the main sugarcane pests (Botelho et al., 1986; Degaspari et al., 1987; Gallo et al., 2002; Beuzelin et al., 2009).
The accumulated richness curves approximated the asymptote level, indicating that the sample size was large enough to represent the communities (Figure 2). Regarding richness $(\mathrm{H}=89.1661 ; p \leq 0.01)$ and abun- 

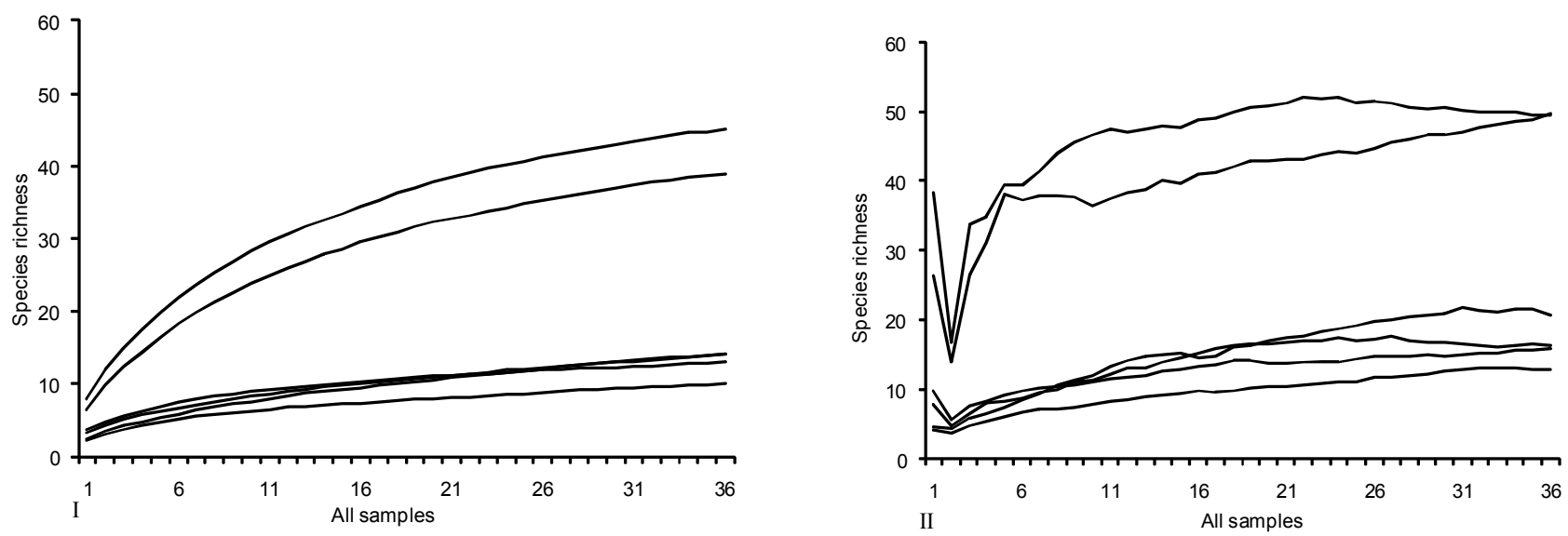

Figure 2 - Species accumulation (I) and estimate richness (II) curves, based on the methods used (A) baiting-honey, (B) baitingsardine, (C) underground traps-honey, (D) underground traps-sardine, (E) pitfall trapping, and (F) all methods combined.

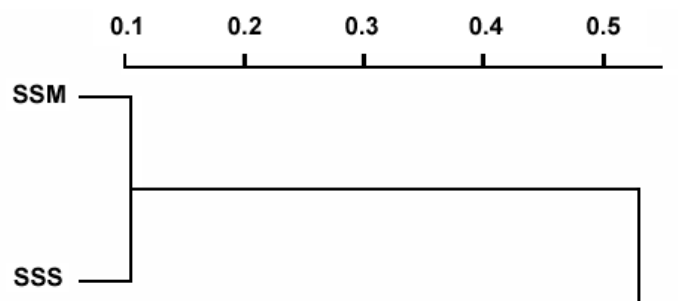

Figure 3 - Dendrogram based on the Bray-Curtis dissimilarity index for three field methods for the study of ants in sugarcane plantations without burning (SSM: underground traps-honey; underground trapssardine; PF: Pitfall trapping; SFM: baiting-honey and SFS: baiting-sardine).

dance $(H=26.6609 ; p \leq 0.01)$, a significant difference was found among the used methods.

In Cerrado or Atlantic and Amazon Forest areas, the use of combined methods to sample ant fauna is the most recommended (Morini et al., 2004; Souza et al., 2007; Lopes and Vasconcelos, 2008). However, the analysis of the species accumulation curve indicates that in sugarcane plantations without burning, pitfall trapping alone is sufficient, as the asymptote was reached and the number of collected species was significantly different (Table 2) when compared to those obtained with other methods. In addition, pitfall traps sampled ant fauna that pre- dates several agricultural pests, such as Dorymyrmex, Pheidole, Solenopsis, Crematogaster, Brachymyrmex, Odontomachus, Pachycondyla, and Ectatomma (Fernandes et al., 1994, 1999, 2001; Fowler et al., 1991; Rossi and Fowler, 2002, 2004). As the maintenance of the straw layer favors the presence of pests (Guimarães et al., 2008), these predatory taxa may contribute to their control in natural cultivation. However, 36 traps were necessary to sample them in a 6-ha sugarcane field.

The choice of the most appropriate sampling method must also take into account the biology of the ant species (Bestelmeyer et al., 2000; Delabie and Reis, 2000; Kaspari, 2000) (Figure 3), since the fauna sampled with the different methods were quite dissimilar. Furthermore, although some taxa were generalists, they were sampled only with underground traps (Crematogaster sp.5, B. heeri (Forel 1874), Hypoponera sp.1, Hypoponera sp.4, Pheidole sp.42 and S. saevissima (Smith, 1855), while other taxa were not sampled with pitfall traps $(B$. heeri, Hypoponera sp. 1, Linepithema iniquum (Mayr), Pheidole sp.5, Pheidole sp. 38, and Pheidole sp. 42) (Table 1).

Almost $65 \%$ of the taxa visited traps with both types of attractants, regardless of the sampling method (Table 1). The use of either sardines or honey did not result in a significant difference in richness results of surface and underground traps (Table 2). According to the analysis of the dendrogram, the ant communities sampled with the same method are similar, regardless of the bait used (Figure 3). Thus, only one attractant type was chosen, in this case sardine in edible vegetable oil, as it is easier to handle in field studies. However, the use of pitfall traps allows the study of the biodiversity of Formicidae, including the taxa considered predators.

\section{Acknowledgements}

To FAEP/UMC for the financial support of the project and to Dr. Rogério Rosa da Silva, of the Museum of Zoology of USP, for confirming ant identifications. To CNPq for the scientific initiation fellowship awarded to the first author. 


\section{References}

Adams, C.T.; Summers, T.E.; Lofgren, C.S.; Focks, D.A.; Prewitt, J.C. 1981. Interrelationship of ants and the sugarcane borer in Florida sugarcane fields. Environmental Entomology 10: 415418.

Alonso, L.E.; Agosti, D. 2000. Biodiversity studies, monitoring and ants: an overview. p. 1-8. In: Agosti, D.; Majer, J.D.; Alonso, L.E.; Schultz, T.R., eds. Ants: standard methods for measuring and monitoring biodiversity. Smithsonian Institution Press, Washington, DC, USA.

Ayres, M.; Ayres, Jr. M.; Ayres, D.L.; Santos, A.S. 2007. BioEstat 5.0: Satatistical Applications in the Areas of Biological Sciences and Medical. Institute for Sustainable Development Mamirauá. IDSM/MCT/CNPq, Brasília, DF, Brazil. 364 p. (in Portuguese).

Bestelmeyer, B.; Agosti, D.; Alonso, L.E.; Brandão, C.R.F.; Brown Jr., W.L.; Delabie, J.H.; Silvestre R. 2000. Field techniques for the study of ground-dwelling ants: an overview, description, and evaluation. p. 122-144. In: Agosti, D.; Majer, J.D.; Alonso, L.E.; Schultz, T.R., eds. Ants: standard methods for measuring and monitoring biodiversity. Smithsonian Institution Press, Washington, DC, USA.

Beuzelin, J.M.; Reagan, T.E.; Akbar, W.; Cormier, H.J.; Flanagan, J.W.; Blouind, D.C. 2009. Impact of hurricane Rita storm surge on sugarcane Borer (Lepidoptera: Crambidae) management in Lousiana. Journal of Economic Entomology 102: 1054-1061.

Bolton, B. 1994. Identification guide to the ant genera of the world. Harvard University Press, Cambridge, MA, USA.

Bolton, B.; Alpert, G.; Ward, P.S.; Naskreccki, P. 2006. Bolton's Catalogue of ants of the world. 1758-2005. Harvard University Press, Cambridge, MA, USA.

Botelho, P.S.M.; Macedo, N.; Almeida, L.C.; Castilho, H.J.; Araujo, J.R. 1986. Technological innovation aiming at the integrated control of Diatraea saccharalis. p. 50-79. In: Botelho, P.S.M., eds. Evaluation of biological control of broaca's sugarcane, Diatraea saccharalis. Coopersucar, Sertãozinho, SP, Brazil. (in Portuguese).

Colwell, R.K. 2007. EstimateS: Statistical estimation of species richness and shared species from sample: version 8.0; user's guide and application. Available at: http:// viceroy.ceb.uconn.ed/EstimateS. [Accessed Dec. 12, 2008].

Degaspari, N.; Macedo, N.; Botelho, P.S.M.; Araujo, J.R.; Almeida, L.C. 1987. Predators and parasites of eggs of Diatraea saccharalis in sugarcane. Pesquisa Agropecuária Brasileira 22: 785-792. (in Portuguese).

Delsinne, T.; Leponce. M.; Theunis, L.; Braet, Y.; Roisin, Y. 2008. Rainfall influences ant sampling in dry forests. Biotropica 40: 590-696.

Delabie, J.H.; Reis, Y.T. 2000. Sympatry and mating flight synchrony of tree species of Cylindromyrmex (Hymenoptera: Formicidae) in Southern Bahia, Brazil, and the importance of Malaise trap for rare ants inventory. Revista Brasileira de Entomologia 44: 109-110.

Fernandes, W.D.; Cavalho, S.L.; Habib, M.E.M. 2001. Betweenseason attraction of cotton boll weevil, Anthonomus grandis (Coleoptera: Curculionidae) adults by its aggregation pheromone. Scientia Agricola 58: 229-234.

Fernandes, W.D.; Oliveira, P.S.; Carvalho, S.L.; Habib, M.E. 1994. Pheidole ants as potential biological control agents of the boll weevil, Anthonomus grandis (Coleoptera: Curculionidae) in southeast Brazil. Journal of Applied Entomology 118: 437-441.

Fernandes, W.D.; Reis, I.A.G.; Astolfi, J.C.P. 1999. Ants as agents of natural control of pests in corn with no-tillage and conventional. Naturalia 24: 237-239. (in Portuguese).

Fernández, F. 2003. Introduction to the Ants in the Neotropical Region. Instituto de Investigación de Recursos Biológicos Alexander Von Humboldt, Bogotá, Colômbia. (in Spanish).

Florentino, H.O.; Moreno, E.V.; Sartori, M.M.P. 2008. Multiobjective optimization of economic balances of sugarcane harvest biomass. Scientia Agricola 65: 561-564.
FNP Consulting and Trade. 2008. Sugarcane Agrianual 2008: Yearbook of the Brazilian Agriculture. FNP, São Paulo, SP, Brazil. (in Portuguese).

Fowler, H.G.; Forti, L.C.; Brandão, C.R.F.; Delabie, J.H.C.; Vasconcelos, H.L. 1991. Nutritional ecology of ants. p. 131209. In: Panizzi, A.R.; Parra, J.R.P., eds. Nutritional ecology of insects and its implications in pest management. Manole, São Paulo, SP, Brazil. (in Portuguese).

Gallo, D.; Nakano, O.; Silveira-Neto, S.; Carvalho, R.P.L.; Batista, G.C.; Berti-Filho, E.; Parra, J.R.P.; Zucchi, R.A.; Alves, S.B.; Vendramim, J.D.; Omoto, C. 2002. Agricultural entomology. Agronômica Ceres, São Paulo, SP, Brazil. 920p. (in Portuguese).

Guimarães, E.R.; Muttoni, M.A.; Muttoni, M.J.R.; Ferro, M.I.T.; Ravaneli, G.C.; Silva, J.A. 2008. Free proline accumulation in sugarcane under water restriction and spittlebug infestation. Scientia Agricola 65: 628-633.

Kaspari, M. 2000. A primer on ant ecology. Chapter 2, p. 9-24. In: Agosti, D.; Majer, J.D.; Alonso, L.E.; Schultz, T.R., eds. Ants: Standard methods for measuring and monitoring biodiversity. Smithsonian Institution Press, Washington, DC, USA.

Legendre, P.; Legendre, L. 1998. Numerical Ecology. 2.ed. Elsevier Press, Amsterdam, Netherlands.

Lopes, C.T.; Vasconcelos, H.L. 2008. Evaluation of three methods for sampling ground-dwelling ants in the Brazilian cerrado. Neotropical Entomology 37: 399-405.

Luff, M.I. 1975. Some features influencing the efficiency of pitfall traps. Oecologia 19: 345-357.

Mentone, T.O.; Morini, M.S.C.; Souza, L.; Braga, S.M.P. 2009. Hymenoptera communities in an agroecosystem using direct seeding in Southeastern Brazil. Sociobiology 53: 473- 486.

Morini, M.S.C.; Yashima, M.; Zene, F.Y.; Silva, R.R.; Jahyny, B. 2004. Observations on the Acanthostichus quadratus (Hymenoptera: Formicidae: Cerapachyinae) visiting underground bait and fruits of the Syagrus romanzoffiana, in an area of the Atlantic Forest, Brazil. Sociobiology 43: 573578 .

Morris, T.I.; Campos, M.; Kidd, N.A.C.; Jervis, W.O.C. 1999. Symondson, Dynamics of the predatory arthropod community in Spanish olive groves. Agronomic Forest Entomology 1: 219228.

National Supply Company [CONAB]. 2009. Available at: http:// www.conab.gov.br [Accessed Feb. 11, 2009]. (in Portuguese).

Negm, A.A.; Hensley, S.D. 1969. Evaluation of certain biological control agents of the sugarcane borer in Louisiana. Journal of Economic Entomology 62: 1008-1013.

Peng, R.K.; Christian, K. 2005. The control efficacy of the weaver ant, Oecophylla smaragdina (Hymenoptera: Formicidae), on the mango leafhopper, Idioscopus nitidulus (Hemiptera: Cicadellidae) in mango orchards in the Northern Territory. International Journal of Pest Management 51: 297-304.

Pendola, A.; New, T.R. 2007. Depth of pitfall traps-does it affect interpretation of ant (Hymenoptera: Formicidae) assemblages? Journal Insect Conservation 11: 199-201.

Risch, S.; Carrol, R.C. 1982. The ecological role of ants in two Mexican agroecosystems. Oecologia 55: 114-119.

Rossi, M. N.; Fowler, H. G. 2002. Manipulation of fire ant density, Solenopsis spp., for short-term reduction of Diatraea saccharalis larval densities in Brazil. Scientia Agricola 59: 389-392.

Rossi, M.N.; Fowler, H.G. 2004. Predaceous at fauna in new sugarcane fields in the state of São Paulo, Brazil. Brazilian Archives of Biology and Technology 47: 805-811.

Santos, A.P.; Cabanas, J.E.; Pereira, J.A. 2007. Abundance and diversity of soil in olive grove ecosystem (Portugal): effect of pifall trap type. European Journal of Soil Biology 43: 77-83.

Sarmiento-M., C.E. 2003. Methodologies for capture and study of ants. p. 201-210. In: Fernández, F. Introduction to the ants in the Neotropical region. Instituto de Investigación de Recursos Biológicos Alexander Von Humbold, Bogotá, Colômbia. (in Spanish). 
Souza, J.L.P.; Moura, C.A.R.; Harada, A.Y.; Franklin, E. 2007. Diversity of species of the genera Crematogaster, Gnamptogenys e Pachycondyla (Hymenoptera: Formicidae) and complementarity of sampling methods during the dry season in an ecological station in the Brazilian State of Pará. Acta Amazônica 37: 649656. (in Portuguese, with abstract in English).

Union of São Paulo Sugarcane [UNICA]. 2009.. Available at: http:/ /www.unica.com.br. [Accessed Fev. 11, 2009]. (in Portuguese).
Ward, P.S. 2000. Broad-scale patterns of diversity in leaf litter ant communities. Chapter 8, p. 99-121. In: Agosti, D.; Majer, J.D.; Alonso, L.E.; Schultz, T.R., eds. Ants: standard methods for measuring monitoring biodiversity. Smithsonian Institution Press, Washington, DC, USA.

Received April 27, 2009

Accepted June 30, 2010 